\title{
Erratum to: Does 2,4-dichlorophenoxyacetic acid (2,4-D) induce genotoxic effects in tissue cultured Allium roots?
}

\author{
Meral Özkul • Çiğdem Alev Özel (D) \\ Deniz Yüzbaşığlu • Fatma Ünal
}

Published online: 8 March 2016

(C) Springer Science+Business Media Dordrecht 2016

\section{Erratum to: Cytotechnology \\ DOI 10.1007/s10616-016-9956-3}

In the original publication of this article, in Table 3, the header has been published incorrectly. The correct Table 3 is provided in this erratum. doi:10.1007/s10616-016-9956-3.

M. Özkul · D. Yüzbaşığlu · F. Ünal Department of Biology, Faculty of Science, Gazi University, Ankara, Turkey

Ç. A. Özel ( $\square)$

Department of Biology Education, Faculty of Gazi

Education, Gazi University, Ankara, Turkey

e-mail: cigdemozel@gmail.com 
Table 3 DNA damaging effects of 2,4-D in Allium cepa root tips

\begin{tabular}{lll}
\hline Concentrations $(\mathrm{mg} / \mathrm{L})$ & Mean tail intensity $\pm \mathrm{SE}$ & Mean tail moment $\pm \mathrm{SE}$ \\
\hline $24 \mathrm{~h}$ & & \\
Control & $57.97 \pm 8.66$ & $113.47 \pm 19.53$ \\
0.67 & $67.42 \pm 5.52$ & $87.52 \pm 10.09$ \\
1.34 & $56.10 \pm 4.66$ & $120.01 \pm 20.53$ \\
2.01 & $51.86 \pm 4.73$ & $110.89 \pm 20.27$ \\
2.68 & $39.30 \pm 4.60$ & $86.89 \pm 16.87$ \\
3.35 & $63.23 \pm 7.37$ & $107.50 \pm 21.87$ \\
4.02 & $45.05 \pm 5.56$ & $75.94 \pm 12.75$ \\
$48 \mathrm{~h}$ & & \\
Control & $42.00 \pm 5.01$ & $62.65 \pm 12.30$ \\
0.67 & $45.03 \pm 4.20$ & $54.06 \pm 6.32$ \\
1.34 & $52.74 \pm 7.65$ & $89.65 \pm 17.32$ \\
2.01 & $44.10 \pm 7.13$ & $74.05 \pm 15.66$ \\
2.68 & $51.09 \pm 5.40$ & $70.53 \pm 9.61$ \\
3.35 & $56.74 \pm 5.12$ & $74.49 \pm 8.07$ \\
4.02 & Not enough cell & Not enough cell \\
\hline
\end{tabular}

